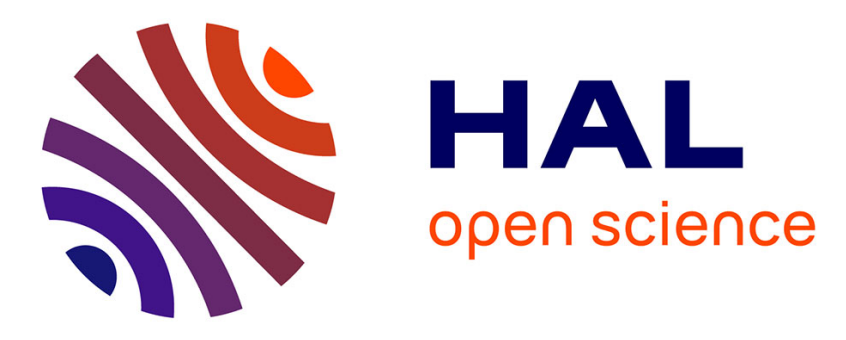

\title{
Tyroscherin and tyroscherin analogs from Pseudallescheria boydii SNB-CN85 isolated from termite Termes cf. hispaniolae
}

Jonathan Sorres, Charlotte Nirma, Morgane Barthélemy, Véronique Eparvier, Didier Stien

\section{To cite this version:}

Jonathan Sorres, Charlotte Nirma, Morgane Barthélemy, Véronique Eparvier, Didier Stien. Tyroscherin and tyroscherin analogs from Pseudallescheria boydii SNB-CN85 isolated from termite Termes cf. hispaniolae. Phytochemistry Letters, 2017, 22, pp.142-144. 10.1016/j.phytol.2017.09.013 . hal-01613323

\section{HAL Id: hal-01613323 \\ https: / hal.sorbonne-universite.fr/hal-01613323}

Submitted on 9 Oct 2017

HAL is a multi-disciplinary open access archive for the deposit and dissemination of scientific research documents, whether they are published or not. The documents may come from teaching and research institutions in France or abroad, or from public or private research centers.
L'archive ouverte pluridisciplinaire HAL, est destinée au dépôt et à la diffusion de documents scientifiques de niveau recherche, publiés ou non, émanant des établissements d'enseignement et de recherche français ou étrangers, des laboratoires publics ou privés. 


\section{Tyroscherin and tyroscherin analogs from}

Pseudallescheria boydii SNB-CN85 isolated from termite Termes cf. hispaniolae

Jonathan Sorres ${ }^{\mathrm{a}}$, Charlotte Nirma ${ }^{\mathrm{a}}$, Morgane Barthélemy ${ }^{\mathrm{a}}$,Véronique Eparvier ${ }^{\mathrm{a},{ }^{*}, \text { Didier }}$ Stien $^{b, *}$

${ }^{a}$ CNRS, Institut de Chimie des Substances Naturelles, UPR 2301, 1 avenue de la Terrasse, 91198 Gif-sur-Yvette, France

${ }^{\mathrm{b}}$ Sorbonne Universités, UPMC Univ. Paris 06, CNRS, Laboratoire de Biodiversité et Biotechnologies Microbiennes (LBBM), Observatoire Océanologique, 66650 Banyuls/Mer, France

\section{Corresponding Authors}

* Tel: +3316982 36 79; Fax: +3316982 37 84; E-mail: veronique.eparvier@cnrs.fr (V. Eparvier). Tel: +33 4301924 76; E-mail: didier.stien@cnrs.fr (D. Stien). 


\section{ABSTRACT}

Two new tyroscherin derivatives: $N$-methyl-tyroscherone (2) and tyroscherin $N, O$-acetonide (3), as well as two known secondary metabolites tyroscherin (1) and pseurotin A (4), were isolated from a solid culture of the termite-borne fungus Pseudallescheria boydii SNB-CN85. The structures were elucidated by spectroscopic analysis and chemical modification. Compound $\mathbf{3}$ was synthesized from tyroscherin (1) in the free amine form by heating in deuterated acetone, followed by deuterium-proton exchange in $\mathrm{MeOH}$. All compounds were tested for their antimicrobial activities on C. albicans and S. aureus, and $\mathbf{2}$ and $\mathbf{3}$ exhibited minimal inhibitory concentrations between 128 and $8 \mu \mathrm{g} \cdot \mathrm{mL}^{-1}$.

Keywords:

Pseudallescheria boydii; termite-borne fungus; tyroscherin; antimicrobial. 
The exploration of secondary metabolites involved in microbial-host interactions has emerged as a successful strategy to identify novel chemical entities and to shed light on the ecology and evolution of defensive association (Beemelmanns et al., 2016; Cantley and Clardy, 2015). These associations are well described in social insects which include ants, bees, termites and wasps, although termites are somewhat less studied than others (Carr et al., 2012; Matsui et al., 2012; Nirma et al., 2015a, 2015b, 2013; Nowak et al., 2010; Sorres et al., 2017; Yan et al., 2011). Indeed, termites microorganisms interactions have been explored mainly to study trophobioses (Carr et al., 2012; Nowak et al., 2010; Yan et al., 2011). Our previous work on Pseudallescheria boydii SNB-CN73 strain had demonstrated that this fungus produced two antimicrobial compounds tyroscherin and $N$-methyl-tyroscherin along with ovalicin and several analogs of these metabolites (Nirma et al., 2013). Interestingly, the random isolation work of entomogenous microbes that was conducted in 2011 yielded six $P$. boydii strains from three different termite nests located in somewhat distant places in French Guiana. After our work on SNB-CN73, it was relevant to investigate other strains see whether or not these strains also produce tyroscherin and analogs.

SNB-CN85 is one of these P. boydii strains. It was isolated from host Termes cf. hispaniolae, whereas SNB-CN73 was isolated from Nasutitermes corniger. In addition to being from different termite species, both nests were located $3 \mathrm{~km}$ apart from each other as the crow flies. Technically, SNB-CN85 was isolated from a surface-sterilized worker placed in a Petri dish containing a solid potato dextrose agar medium. It was identified by amplification and sequencing of the nuclear ribosomal internal transcribed spacer region ITS4 and comparison with NCBI database of sequences. The EtOAc extract of a solid culture of $P$. boydii SNBCN85 exhibited significant activity against C. albicans $\left(\mathrm{MIC}=8 \mu \mathrm{g} \cdot \mathrm{mL}^{-1}\right)$. Chemical 
investigation of this extract led to the isolation of tyroscherin (1) (Hayakawa Y, Yamashita T, Mori T, Nagai K, Shin-Ya K, 2004; Katsuta et al., 2008; Nirma et al., 2013) and pseurotin A (4) (Bloch and Tamm, 1981; Hayashi et al., 2003) along with two new tyroscherin analogs $N$ methyl-tyroscherone (2) and tyroscherin $\mathrm{N}, \mathrm{O}$-acetonide (3).

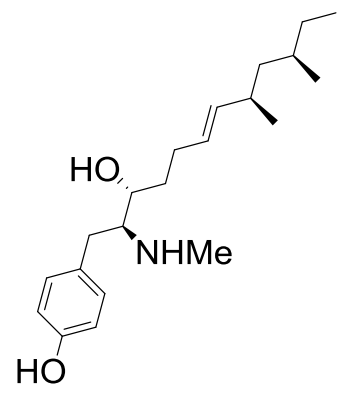

Tyroscherin (1)

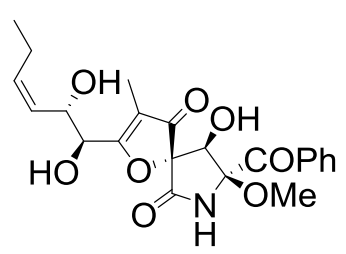

Pseurotin A (4)

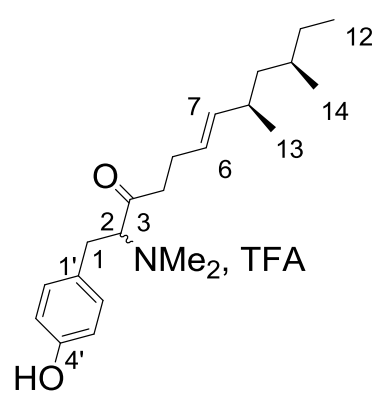

N-Methyl-tyroscherone (2), TFA salt

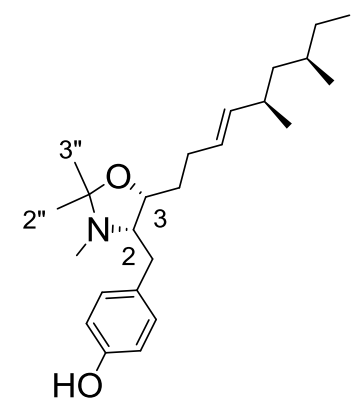

Tyroscherin acetonide (3)

Fig. 1. Structures of compounds 1-4 with configurations presented as absolute

Compound 2 TFA salt was obtained as white amorphous powder. HRESIMS analysis indicated a molecular formula of $\mathrm{C}_{22} \mathrm{H}_{35} \mathrm{NO}_{2}\left(\mathrm{~m} / z\right.$ for 346.2749 for $\left.[\mathrm{M}+\mathrm{H}]^{+}\right)$, implying 6 degrees of unsaturation, i.e., one more than for $N$-methyl-tyroscherin with the same number of carbons. Preliminary inspection of the ${ }^{1} \mathrm{H}$ and ${ }^{13} \mathrm{C}$ NMR spectra, along with the analysis of the HSQC correlations confirmed that compound $\mathbf{2}$ was a tyroscherin analog (Table 1). The main difference between these compounds was for ${ }^{1} \mathrm{H}$ and ${ }^{13} \mathrm{C}$ chemical shifts in the $\mathrm{C}-2-\mathrm{C}-4$ spin system. In particular, the tyroscherin $\alpha$-hydroxyl proton $\mathrm{H}-3$ at $\delta_{\mathrm{H}} 3.85 \mathrm{ppm}$ was absent 
in 2. Also, ${ }^{13} \mathrm{C}$ NMR spectrum of 2 displayed a carbonyl signal at $\delta_{\mathrm{C}} 207.7 \mathrm{ppm}$, and we also observed the lack of the carbinol at $\delta_{\mathrm{C}} 68.7 \mathrm{ppm}$ in tyroscherin. In $\mathrm{HMBC}$, methylene protons in position 1 at $\delta_{\mathrm{H}} 3.37$ and $2.96 \mathrm{ppm}$, methylene protons in position 4 at $\delta_{\mathrm{H}} 2.37$ and 2.00 ppm, and the methine proton at $\delta_{\mathrm{H}} 4.45 \mathrm{ppm}$ all correlated with this carbonyl. Consequently, it was clear that compound $\mathbf{2}$ had a carbonyl in position 3 . The complete proton assignment of compound 2 was deduced from the careful examination of COSY, HSQC and HMBC correlations. However, although the overall integration of protons was correct, it was noticed that many signals in the ${ }^{1} \mathrm{H}$ and ${ }^{13} \mathrm{C}$ NMR experiments were split. Attempts to separate two different compounds by HPLC failed. Since all NMR data were almost identical, we assumed that the position 2 in compound $\mathbf{2}$ may in fact epimerize due to the presence of the carbonyl group at $\mathrm{C}-3$, yielding a mixture of epimers. Treatment of $\mathbf{2}$ with $\mathrm{NaOD}$ in $\mathrm{CD}_{3} \mathrm{OD}$ at room temperature provided $N$-methyl-tyroscherone-2- $d(\mathbf{2}-\boldsymbol{d})$ with $69 \%$ conversion (as measured by ${ }^{1} \mathrm{H}$ NMR by integration of the residual $\mathrm{H}-2$ proton signal), confirming that carbon $\mathrm{C}-2$ is most prone to epimerization. We concluded then that compound $\mathbf{2}$ was isolated in the form of a mixture of $2 R$ and $2 S$ epimers. Biosynthetic considerations would provide the configurations of other asymmetric centres as being identical to those observed for tyroscherin $(8 R$ and $10 R)$. Compound 2 was named $N$-methyl-tyroscherone from a putative oxo analog of tyroscherin.

The molecular formula of 3 was determined to be $\mathrm{C}_{24} \mathrm{H}_{39} \mathrm{NO}_{2}$ by HRESIMS ( $\mathrm{m} / z 374.3046$ for $[\mathrm{M}+\mathrm{H}]^{+}$), indicating the presence of three additional carbons compared to the molecular formula of $\mathbf{1}$. Compound $\mathbf{3}$ was originally isolated as TFA salt, and was converted to the free base for $1 \mathrm{D}$ and 2D NMR analyses. The ${ }^{1} \mathrm{H}$ NMR spectra of compounds $\mathbf{1}$ and $\mathbf{3}$ presented some similarities, indicating that $\mathbf{3}$ was also a tyroscherin analog (Table 1). For example, 
compound $\mathbf{3}$ had para-substituted aromatic systems characteristic signals at $\delta_{\mathrm{H}} 7.06(\mathrm{~d}, J=$ $8.6 \mathrm{~Hz}, 2 \mathrm{H})$ and $\delta_{\mathrm{H}} 6.71(\mathrm{~d}, J=8.6 \mathrm{~Hz}, 2 \mathrm{H})$. It also had the tyroscherin series methyl signals $\delta_{\mathrm{H}} 0.90(\mathrm{~d}, J=6.7 \mathrm{~Hz}, 3 \mathrm{H}), 0.86(\mathrm{t}, J=7.3 \mathrm{~Hz}, 3 \mathrm{H})$, and $0.81(\mathrm{~d}, J=6.5 \mathrm{~Hz}, 3 \mathrm{H})$, ethylenic protons at $\delta_{\mathrm{H}} 5.31$ and $\delta_{\mathrm{H}} 5.10$, a carbinol at $\delta_{\mathrm{H}} 3.92$, and a proton $\alpha$ to a nitrogen at $\delta_{\mathrm{H}} 3.23$. On the other hand, the remarkable difference between compounds $\mathbf{1}$ and $\mathbf{3}$ in ${ }^{1} \mathrm{H}$ NMR was the presence of 2 additional singlet signals integrating for $3 \mathrm{H}$ at $\delta_{\mathrm{H}} 1.33$ and 1.14 in compound 3. 


\section{Table 1}

NMR spectroscopic data for $N$-methyl-tyroscherone (2) TFA salt (two diastereoisomers 1:1) and tyroscherin acetonide (3) at $500 \mathrm{MHz}$ in

\section{$\mathrm{CD}_{3} \mathrm{OD}$}

\begin{tabular}{|c|c|c|c|c|c|c|c|c|}
\hline \multirow{2}{*}{ position } & \multicolumn{4}{|c|}{$\mathrm{N}$-Methyl-tyroscherone (2) } & \multicolumn{4}{|c|}{ Tyroscherin $N, O$-acetonide (3) } \\
\hline & $\delta_{\mathrm{C}}$, type & $\delta_{\mathrm{H}}(J$ in $\mathrm{Hz})$ & COSY & $\mathrm{HMBC}^{\mathrm{a}}$ & $\delta_{\mathrm{C}}$ & $\delta_{\mathrm{H}}(J$ in $\mathrm{Hz})$ & COSY & $\mathrm{HMBC}^{\mathrm{a}}$ \\
\hline \multirow[t]{2}{*}{1} & \multirow[t]{2}{*}{$34.33 / 34.28, \mathrm{CH}_{2}$} & a: $3.361 / 3.365$, dd $(13.7,5.8)$ & $1 b, 2$ & $2,3,1^{\prime}, 2^{\prime}$ & \multirow{2}{*}{$34.4, \mathrm{CH}_{2}$} & a: 2.83, dd $(14.3,5.6)$ & $1 b, 2$ & $2,3,1^{\prime}, 2^{\prime}$ \\
\hline & & b: $2.956 / 2.964, \mathrm{dd}(13.7,9.7)$ & $1 \mathrm{a}, 2$ & $2,3,1^{\prime}, 2^{\prime}$ & & b: $2.57, \mathrm{dd}(14.3,9.1)$ & $1 \mathrm{a}, 2$ & $2,3,1^{\prime}, 2^{\prime}$ \\
\hline 2 & $74.2, \mathrm{CH}$ & $4.445 / 4.452, \mathrm{dd}(9.7,5.8)$ & $1 \mathrm{a}, 1 \mathrm{~b}$ & $1,3,1$ & $66.8, \mathrm{CH}$ & 3.23 , ddd $(9.1,7.0,5.6)$ & $1 \mathrm{a}, 1 \mathrm{~b}, 3$ & 1 \\
\hline 3 & 207.75/207.68, C & & & & $77.6, \mathrm{CH}$ & 3.92, ddd $(10.3,7.0,3.1)$ & 2,4 & \\
\hline \multirow[t]{2}{*}{4} & \multirow[t]{2}{*}{$44.9 / 44.8, \mathrm{CH}_{2}$} & a: $2.37, \mathrm{~m}$ & $4 b, 5 a, 5 b$ & $3,5,6$ & \multirow[t]{2}{*}{$32.0, \mathrm{CH}_{2}$} & \multirow[t]{2}{*}{$1.55, \mathrm{~m}$} & \multirow[t]{2}{*}{$3,5 \mathrm{a}$} & \multirow[t]{2}{*}{3,6} \\
\hline & & $\mathrm{b}: 2.00, \mathrm{~m}$ & $4 a, 5 a, 5 b$ & $3,5,6$ & & & & \\
\hline \multirow[t]{2}{*}{5} & \multirow[t]{2}{*}{$26.7, \mathrm{CH}_{2}$} & $\mathrm{a}: 2.12, \mathrm{~m}$ & $4 a, 4 b, 5 b, 6$ & $3,4,6,7$ & \multirow{2}{*}{\multicolumn{2}{|c|}{$\begin{array}{r}29.5, \mathrm{CH}_{2} \text { a: } 2.12, \mathrm{~m} \\
\text { b: } 1.93, \mathrm{~m}\end{array}$}} & $4,5 b$ & $4,6,7$ \\
\hline & & b: $1.99, \mathrm{~m}$ & $4 a, 4 b, 5 a, 6$ & $3,4,6,7$ & & & $4,5 a, 6$ & $4,6,7$ \\
\hline 6 & 127.3, CH & $5.17, \mathrm{~m}$ & $5 a, 5 b, 7$ & $4,5,7,8$ & $137.7, \mathrm{CH}$ & {$[5.31, \mathrm{~m}$} & $5 a, 5 b, 7$ & 5,8 \\
\hline 7 & 139.21/139.18, $\mathrm{CH}$ & $5.14, \mathrm{~m}$ & 6,8 & $5,6,8,9,13$ & $129.0, \mathrm{CH}$ & [ 5.10, ddt $(15.3,8.4,1.4)$ & 6,8 & 5 \\
\hline 8 & $35.82 / 35.79, \mathrm{CH}$ & $2.11, \mathrm{~m}$ & $7,9 a, 9 b, 13$ & 6,7 & $35.7, \mathrm{CH}$ & $2.10, \mathrm{~m}$ & & \\
\hline \multirow[t]{2}{*}{9} & \multirow[t]{2}{*}{$45.59 / 45.58, \mathrm{CH}_{2}$} & $\mathrm{a}: 1.21, \mathrm{~m}$ & $8,9 b, 10$ & $7,8,10,11,13,14$ & \multirow{2}{*}{$45.5, \mathrm{CH}_{2}$} & $\mathrm{a}: 1.21, \mathrm{~m}$ & $9 b$ & \multirow{5}{*}{$7,8,10,11$} \\
\hline & & b: 0.97, ddd (13.5 8.6 5.0) & $8,9 \mathrm{a}, 10$ & $7,8,10,11,13,14$ & & b: $0.97, \mathrm{~m}$ & $9 a, 10$ & \\
\hline 10 & $33.3, \mathrm{CH}$ & $1.26, \mathrm{~m}$ & & & $32.9, \mathrm{CH}$ & $1.30, \mathrm{~m}$ & 14 & \\
\hline \multirow[t]{2}{*}{11} & \multirow[t]{2}{*}{$31.3, \mathrm{CH}_{2}$} & $\mathrm{a}: 1.29, \mathrm{~m}$ & $11 b, 12$ & & \multirow[t]{2}{*}{$31.2, \mathrm{CH}_{2}$} & $\mathrm{a}: 1.27, \mathrm{~m}$ & 12 & \\
\hline & & $\mathrm{b}: 1.13, \mathrm{~m}$ & $12,11 \mathrm{a}$ & $9,10,12,14$ & & $\mathrm{~b}: 1.14, \mathrm{~m}$ & 12 & \\
\hline 12 & $11.81 / 11.79, \mathrm{CH}_{3}$ & $0.85 / 0.86, \mathrm{t}(7.3)$ & $11 \mathrm{a}, 11 \mathrm{~b}$ & 10,11 & $11.6, \mathrm{CH}_{3}$ & $0.86, \mathrm{t}(7.3)$ & $11 \mathrm{a}, 11 \mathrm{~b}$ & 10,11 \\
\hline 13 & $22.32 / 22.29, \mathrm{CH}_{3}$ & $0.898 / 0.899, \mathrm{~d}(6.7)$ & 8 & $7,8,9$ & $22.4, \mathrm{CH}_{3}$ & $0.90, \mathrm{~d}(6.7)$ & 8 & $7,8,9$ \\
\hline 14 & $19.44 / 19.41, \mathrm{CH}_{3}$ & $0.804 / 0.806, \mathrm{~d}(6.5)$ & 10 & $9,10,11$ & $19.3, \mathrm{CH}_{3}$ & $0.81, \mathrm{~d}(6.5)$ & 10 & $9,10,11$ \\
\hline 1 ' & $125.43 / 125.40, \mathrm{C}$ & & & & $130.6, \mathrm{C}$ & & & \\
\hline $26^{\prime}$ & $131.7, \mathrm{CH}$ & 7.10, bd $(8.7)$ & $3 ' / 5$ & $1,4^{\prime}, 2^{\prime} / 6^{\prime}$ & $130.7, \mathrm{CH}$ & [ 7.06, d (8.6) & $3 ' / 5^{\prime}$ & $1,4^{\prime}, 2^{\prime} / 6^{\prime}$ \\
\hline $3 ' / 5$ & $117.3, \mathrm{CH}$ & $6.80, \mathrm{bd}$ & $2 ' / 6 '$ & $1^{\prime}, 4^{\prime}, 3^{\prime} / 5^{\prime}$ & $116.0, \mathrm{CH}$ & [ $6.71, \mathrm{~d}(8.6)$ & $2 ' / 6$ & $1^{\prime}, 4^{\prime}, 3^{\prime} / 5^{\prime}$ \\
\hline $4^{\prime}$ & $158.7, \mathrm{C}$ & & & & $156.5, \mathrm{C}$ & & & \\
\hline $\mathrm{NMe}$ & 42.6 (broad), $\mathrm{CH}_{3}$ & $2.90, \mathrm{bs}$ & & 2 & $34.5, \mathrm{CH}_{3}$ & $2.20, \mathrm{~s}$ & & $2,1^{\prime \prime}$ \\
\hline $1 "$, & & & & & $95.6, \mathrm{C}$ & & & \\
\hline $2 "$ & & & & & $26.8, \mathrm{CH}_{3}$ & $1.33, \mathrm{~s}$ & & 1, \\
\hline 3, & & & & & $20.0, \mathrm{CH}_{3}$ & $1.14, \mathrm{~s}$ & & $1 ", 2$, \\
\hline
\end{tabular}

${ }^{\mathrm{a}} \mathrm{HMBC}$ correlations, optimized for $8 \mathrm{~Hz}$, are from proton(s) stated to the indicated carbon. 
These two additional methyls were in geminal position, both linked to $\mathrm{C} 1$ " as witnessed by HMBC. The correlation between the NMe and C1" as well as the C1" chemical shift at $\delta_{\mathrm{C}} 95.6$ confirmed the existence of an oxazolidine ring including carbons $\mathrm{C} 2, \mathrm{C} 3$ and $\mathrm{C} 1$ ". Compound $\mathbf{3}$ was named tyroscherin $\mathrm{N}, \mathrm{O}$-acetonide. Its presence was confirmed in the HPLC profile of the crude extract, and we therefore assumed that this compound did not originate from an unwanted addition of tyroscherin onto acetone after extraction (no acetone was used in the process).

NMR spectral data of $\mathbf{3}$ were recorded in $\mathrm{CD}_{3} \mathrm{OD}$ for 12 hours. Interestingly, after this period, we observed that both methyl signals at $\delta_{\mathrm{H}} 1.33$ (H2”) and $1.14 \mathrm{ppm}$ (H3”) had disappeared in ${ }^{1} \mathrm{H}$ NMR. Deuteration had occurred in these positions yielding $\mathbf{3 - d _ { 6 }}$, most likely via a transient acyclic enamine resulting from the opening of the oxazolidine ring (Scheme 1). Besides, deuteriums were exchanged back to protons in anhydrous methanol. Also, after a long time in solution ( $\sim 1$ year), it was found that compound $\mathbf{3}$ had been converted into tyroscherin, therefore confirming the absolute configuration of $\mathbf{3}$ as $2 S, 3 R, 8 R, 10 R$. Further confirmation was obtained by reacting tyroscherin with acetone$d_{6}$ under reflux for 50 hours (Scheme 1). $3-\boldsymbol{d}_{6}$ was obtained and was converted in $\mathbf{3}$ in methanol. The overall yield was $88 \%$. The NMR data for $\mathbf{3}-\boldsymbol{d}_{\mathbf{6}}$ and $\mathbf{3}$ obtained with this process were identical to those of natural $\mathbf{3}$ and of $\mathbf{3}-\boldsymbol{d}_{\mathbf{6}}$ obtained by deuteration of natural 3. Note that acetonides are rather uncommon in Nature (Shao et al., 2011; Yu et al., 2016). Compound $\mathbf{3}$ was isolated without using acetone, neither for extraction, nor for purification. Also, condensation of tyroscherin with acetone- $d_{6}$ did not occur at room temperature. Fungal cultures can produce acetone (Scotter et al., 2005), which we suppose was trapped by tyroscherin in the culture medium. We feel that compound $\mathbf{3}$ 
should therefore be considered as a genuine natural product although the condensation may not have been enzyme-catalyzed.

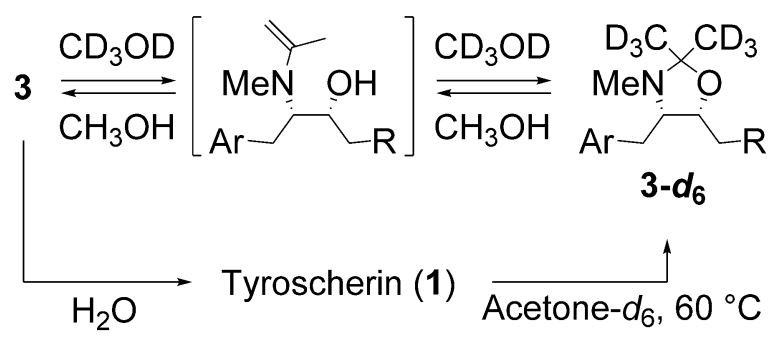

\section{Scheme 1}

The antimicrobial potential of compounds 1-4 was evaluated against human pathogens Staphylococcus aureus and Candida albicans (Table 2). In accordance with the literature, tyroscherin (1) was strongly active on both pathogens, and pseurotin A (4) was inactive (Lu et al., 2014; Nirma et al., 2013). Interestingly, both tyroscherin analogs were significantly active, with minimal inhibitory concentrations of $8 \mu \mathrm{g} \cdot \mathrm{mL}^{-1}$ for $\mathbf{2}$ on $S$. aureus, and 16 and $8 \mu \mathrm{g} . \mathrm{mL}^{-1}$ for 3 on C. albicans and S. aureus, respectively. In addition, compounds $\mathbf{1 - 3}$ showed a moderate cytotoxicity towards MRC5 cells with $\mathrm{IC}_{50}$ in the $20-50 \mu \mathrm{g} \cdot \mathrm{mL}^{-1}$ range.

Table 2. Antimicrobial activity of compounds 1-4

\begin{tabular}{lll}
\hline & \multicolumn{2}{l}{ MIC $\left(\mu \mathrm{g} \cdot \mathrm{mL}^{-1}\right)$} \\
Molecule & C. albicans $^{\mathrm{a}}$ & S. aureus $^{\mathrm{b}}$ \\
\hline Tyroscherin (1) & 16 & 8 \\
$N$-Methyl-tyroscherone (2) & 128 & 8 \\
Tyroscherin $N$, O-acetonide (3) & 16 & 8 \\
Pseurotin A (4) & $>128$ & $>128$ \\
Oxacillin & - & 4 \\
Fluconazole & 4 & - \\
\hline${ }^{\mathrm{a}}$ Candida albicans ATCC 10213 & \\
${ }^{\mathrm{b}}$ Staphylococcus aureus ATCC 29213
\end{tabular}

In conclusion, this article reports $\mathrm{N}$-methyl-tyroscherone and tyroscherin $\mathrm{N}, \mathrm{O}$-acetonide 
for the first time. These compounds were isolated along with pseurotin A and tyroscherin from the termite-borne fungus Pseudallescheria boydii SNB-CN85. Their relative and absolute configurations were determined by chemical modifications and comparison with tyroscherin. Along with our previous report,(Nirma et al., 2013) this article further demonstrates that tyroscherin-producing Pseudallescheria fungal strains can be found in several termite nests in French Guiana. The exact occurrence of Pseudallescheria sp. and the ability of this strain to deliver tyroscherin to its host termites are currently being investigated.

\section{Acknowledgment}

This work has benefited from an "Investissement d'Avenir" grant of the Agence Nationale de la Recherche (CEBA, ref. ANR-10-LABX-0025, France).

\section{Appendix A. Supplementary data}

Supplementary data associated with this article include experimental information, full spectroscopic data, and NMR spectra of compounds 1-4. It can be found at http://

\section{References}

Beemelmanns, C., Guo, H., Rischer, M., Poulsen, M., 2016. Natural products from microbes associated with insects. Beilstein J. Org. Chem. 12, 314-327.

Bloch, P., Tamm, C., 1981. Isolation and structure of pseurotin A, a microbial metabolite of Pseudeurotium ovalis Stolk with an unusual heterospirocyclic system. Helv. 
Chim. Acta 64, 304-315.

Cantley, A.M., Clardy, J., 2015. Animals in a bacterial world: opportunities for chemical ecology. Nat. Prod. Rep. 32, 888-892.

Carr, G., Poulsen, M., Klassen, J.L., Hou, Y., Wyche, T.P., Bugni, T.S., Currie, C.R., Clardy, J., 2012. Microtermolides A and B from termite-associated streptomyces sp. and structural revision of vinylamycin. Org. Lett. 14, 2822-2825.

Hayakawa Y, Yamashita T, Mori T, Nagai K, Shin-Ya K, W.H., 2004. Structure of tyroscherin, an antitumor antibiotic against IGF-1-dependent cells from Pseudallescheria sp. J. Antibiot. 57, 634-638.

Hayashi, Y., Shoji, M., Yamaguchi, S., Mukaiyama, T., Yamaguchi, J., Kakeya, H., Osada, H., 2003. Asymmetric total synthesis of pseurotin A. Org. Lett. 5, 22872290.

Katsuta, R., Shibata, C., Ishigami, K., Watanabe, H., Kitahara, T., 2008. Synthesis and structure revision of tyroscherin, a growth inhibitor of IGF-1-dependent tumor cells. Tetrahedron Lett. 49, 7042-7045.

Lu, Q.-Q., Tian, J.-M., Wei, J., Gao, J.-M., 2014. Bioactive metabolites from the mycelia of the basidiomycete Hericium erinaceum. Nat. Prod. Res. 28, 1288-1292.

Matsui, T., Tanaka, J., Namihira, T., Shinzato, N., 2012. Antibiotics production by an actinomycete isolated from the termite gut. J. Basic Microbiol. 52, 731-735.

Nirma, C., Eparvier, V., Stien, D., 2015a. Antibacterial ilicicolinic Acids C and D and ilicicolinal from Neonectria discophora SNB-CN63 isolated from a termite nest. J. Nat. Prod. 78, 159-162.

Nirma, C., Eparvier, V., Stien, D., 2015b. Reactivation of antibiosis in the entomogenous fungus Chrysoporthe sp. SNB-CN74. J. Antibiot. 68, 586-590.

Nirma, C., Eparvier, V., Stien, D., 2013. Antifungal agents from Pseudallescheria boydii 
SNB-CN73 isolated from a Nasutitermes sp. termite. J. Nat. Prod. 76, 988-991.

Nowak, M.A., Tarnita, C.E., Wilson, E.O., 2010. The evolution of eusociality. Nature $466,1057-1062$.

Scotter, J.M., Langford, V.S., Wilson, P.F., McEwan, M.J., Chambers, S.T., 2005. Realtime detection of common microbial volatile organic compounds from medically important fungi by Selected Ion Flow Tube-Mass Spectrometry (SIFT-MS). J. Microbiol. Methods 63, 127-134.

Shao, C.L., Wu, H.X., Wang, C.Y., Liu, Q.A., Xu, Y., Wei, M.Y., Qian, P.Y., Gu, Y.C., Zheng, C.J., She, Z.G., Lin, Y.C., 2011. Potent antifouling resorcylic acid lactones from the gorgonian-derived fungus Cochliobolus lunatus. J. Nat. Prod. 74, 629-633.

Sorres, J., Nirma, C., Eparvier, V., Stien, D., 2017. Pseudallicins A-D, Four Complex Ovalicin Derivatives from Pseudallescheria boydii SNB-CN85. Org. Lett. 19, $3978-3981$.

Yan, S., Li, S., Wu, W., Zhao, F., Bao, L., Ding, R., Gao, H., Wen, H.A., Song, F., Liu, H.W., 2011. Terpenoid and phenolic metabolites from the fungus Xylaria sp. associated with termite nests. Chem. Biodivers. 8, 1689-1700.

Yu, J.S., Moon, E., Choi, S.U., Kim, K.H., 2016. Asarotonide, a new phenylpropanoid with a rare natural acetonide group from the rhizomes of Acorus gramineus. Tetrahedron Lett. 57, 1699-1701. 